\title{
KEDUDUKAN FATWA DALAM KONSTRUKSI HUKUM ISLAM
}

\author{
Ibnu Elmi A.S. Pelu \\ Institut Agama Islam Negeri Palangka Raya, Kalimantan Tengah, Indonesia \\ ibnu.elmi@iain-palangkaraya.ac.id \\ Received:11-06-2019; Revised: 14-06-2019; Accepted: 20-12-2019
}

\begin{abstract}
Fatwas as a result of human thought use the main legal sources, but can be categorized into ijtihad, because the process of determining fatwas is done through methods determined by the science of ushul fiqh. In judicial practice in Indonesia, fatwas can be included as legal experts' opinions. Fatwa is a legal opinion or opinion on Islamic law on considerations that can be taken from legal sources as legal considerations for judges to give decisions. Fatwas are issued by Islamic scholars or jurisprudents who are able to raise the problem of needs that require basic answers on the basis of the law about activities or activities that can be religious or non-religious in nature. Fatwa becomes one of the sessions in Islamic law to provide answers and solutions to problems raised by the people. While the Muslims at the time of the fatwa as a reference in contradiction and behavior. The position of the fatwa among the general public, is like the argument among the mujtahids (al-Fatwa fi Haqqil 'Ami kal Adillah fi Haqqil Mujtahid), that is, the placement of the fatwa in the construction of Islamic law that asks for the proposition of the mujtahid. The position of fatwa in the construction of Islamic law becomes the legal basis for an act or activity which is good in nature muamalah. The classic fatwa that was transferred (ikhtiyariah) or a choice that is not legally binding. However, associating morals with mustafti or someone who requests a fatwa. This is reinforced through the theory of acceptance of Islamic law, which is the basis of the obligation of every Muslim to approve and comply with Islamic law, the source of which is fatwa, both from philosophical, juridical, and sociological sources.

Keywords: position of fatwa, construction, Islamic law
\end{abstract}

\section{INTISARI}

Fatwa sebagai hasil dari pemikiran manusia bukanlah sumber hukum utama, namun dapat dikategorikan ke dalam ijtihad, sebab proses penetapan fatwa dilakukan melalui metodemetode yang ditetapkan oleh ilmu ushul fikih. Pada praktik peradilan di Indonesia, fatwa dapat dimasukkan sebagai pendapat ahli hukum. Fatwa adalah legal opinion atau pendapat mengenai hukum Islam atas suatu persoalan yang dapat dijadikan sumber hukum sebagai pertimbangan hukum bagi hakim untuk memberikan putusan. Fatwa dikeluarkan oleh para ulama atau ahli fikih Islam yang mampu mengangkat permasalahan akibat kebutuhan siapa yang butuh dasar jawaban sebagai landasan hukum suatu perbuatan atau kegiatan yang sifatnya bisa keagamaan atau non-keagamaan. Fatwa menjadi salah satu institusi dalam hukum Islam untuk memberikan jawaban dan solusi terhadap problem yang dihadapi umat. Bahkan umat Islam pada umumnya menjadikan fatwa sebagai rujukan di dalam bersikap dan bertingkah laku.Sebab posisi fatwa di 
kalangan masyarakat umum, laksana dalil di kalangan para mujtahid (al-Fatwa fi Haqqil 'Ami kal Adillah fi Haqqil Mujtahid), artinya, kedudukan fatwa dalam konstruksi hukum Islam sebagaimana dalil bagi mujtahid. Kedudukan fatwa dalam konstruksi hukum Islam yaitu menjadi landasan hukum terhadap suatu perbuatan atau kegiatan yang sifatnya ibadah maupun muamalah. Fatwa klasik bersifat opsional (ikhtiyariah) atau pilihan yang tidak mengikat secara legal. Namun, mengikat secara moral bagi mustafti atau seseorang yang meminta fatwa. Hal ini dikuatkan melalui teori penerimaan otoritas hukum Islam, yang menjadi dasar kewajiban setiap umat Islam untuk tunduk dan patuh terhadap hukum Islam, yang sumbernya salah satunya adalah fatwa, baik dari aspek filosofis, yuridis, dan sosiologis.

Kata kunci: kedudukan fatwa, konstruksi, hukum Islam

\section{A. Pendahuluan}

Sumber utama hukum Islam adalah Al Qur'an dan Hadis.Hanya saja, tidak semua umat Islam mampu memahami Al Qur'an dan Hadis secara langsung. Terlebih dengan banyaknya nash-nash yang bersifat umum, seperti ayat-ayat mutasyabihat maupun ayatayat zhanny yang memerlukan penjabaran lebih detil.Di sisi lain, umat Islam terikat dengan kewajiban untuk tunduk dan patuh terhadap hukum Islam. Permasalahan ini apabila dibiarkan akan mengakibatkan terjadinya kebingungan yang bahkan dapat menimbulkan kekosongan hukum. Ketika umat Islam tidak mampu menangkap maksud hukum yang terkandung di dalam nash, disinilah fatwa, sebagaimana hasil ijtihad para mujtahid, mengambil peran sebagai "penjelas" dan "jawaban pertanyaan hukum".

Permasalahan-permasalahan hukum terus berkembang seiring perkembangan zaman. Sedangkan nash Al Qur'an dan Hadis sudah terhenti secara kuantitas. Pada kondisi seperti ini, berdasarkan kepada teori maqashid asy syari'ah, dan teori otoritas hukum Islam, fatwa dapat menjadi salah satu alternatif dalam menguraikan permasalahan yang berorientasi kepada kemaslahatan dalam berbagai masalah dan perkembangan hukum yang tidak relevan dengan perkembangan zaman. ${ }^{1}$

\section{B. Metode Penelitian}

Penelitian ini merupakan penelitian hukum normatif, di mana tidak perlu membenarkan temuan para ahli hukum, terhadap posisi dan kedudukan fatwa dalam konstruksi hukum Islam. Beberapa topik ruang lingkup penelitian ini adalah berkaitan

\footnotetext{
${ }^{1}$ Jefry Tarantang, Teori dan Aplikasi Pemikiran Kontemporer dalam Pembaharuan Hukum Keluarga Islam, Jurnal Transformatif Vol. 2, No. 1, April 2018, h. 29.
} 
dengan sumber hukum dalam Islam, fatwa sebagai sumber hukum Islam, konstruksi fatwa sebagai sumber hukum Islam.

Untuk memperoleh hasil yang komprehensif, penelitian ini menggunakan tiga pendekatan yang terdiri dari pendekatan perundang-undangan, pendekatan historis, dan pendekatan konseptual. Dalam hal pendekatan perundang-undangan, kedudukan fatwa bertentangan karena tidak didukung oleh Undang-Undang No.12 Tahun 2011 tentang pembentukan peraturan perundang-undangan. Namun, menurut pembukaan peraturan (Pembukaan Undang-Undang Dasar 1945), fatwa sebenarnya menjadi sumber hukum Islam. Pendekatan historis menyoroti aspek historis dan sosiologis dari fatwa mulai dari kehidupan Muhammad hingga era dinamikaIslam kontemporer. Pendekatan terakhir, pendekatan konseptual, terdiri dari tiga aspek: pertama, aspek filosofis yang merupakan hakikat fatwa; kedua, aspek yuridis yang menjadi legalitas fatwa saat ini; dan ketiga, aspek sosiologis menyoroti keberadaan fatwa dalam kehidupan umat.

\section{Hasil dan Pembahasan}

\section{Sumber Hukum dalam Islam}

Sumber hukum berarti segala sesuatu yang berupa tulisan, dokumen, dan naskah yang digunakan sebagai pedoman dalam melakukan tindakan hukum. Utrecht membagi sumber hukum menjadi dua, yakni sumber hukum formil dan materil. ${ }^{2}$ Sumber hukum pada dasarnya berbeda dengan landasan hukum atau dasar hukum atau payung hukum. Oleh sebab itu, sumber hukum lebih menunjukkan pada pengertian tempat dari mana asal suatu nilai atau norma berasal. Sedangkan yang dimaksud dengan dasar hukum (legal ground) atau landasan hukum (legal basis) atau payung hukum adalah norma hukum yang mendasari suatu tindakan atau perbuatan hukum tertentu sehingga dapat dianggap sah dan dapat dibenarkan secara hukum. ${ }^{3}$

Menurut Jimly Asshiddiqie yang penulis kutip dari Pipin Syarifin, sumber hukum yang dimaksud dalam sistem berpikir hukum Islam di satu pihak digambarkan sebagai sumber rujukan, tetapi di pihak lain diidentikkan sebagai metode penalaran hukum (legal reasoning). Misalnya sumber hukum dalam Islam adalah Al Qur'an, As-Sunnah, dan

\footnotetext{
${ }^{2}$ Sumber hukum formil adalah tempat atau sumber suatu peraturan memperoleh kekuatan hukum.Sumber hukum materil merupakan faktor yang membantu pembentukan hukum. Lihat: Ellydar Chaidir dan Sudi Fahmi, Hukum Perbandingan Konstitusi, Yogyakarta: Total Media, 2010, h. 78-79.

${ }^{3}$ Pipin Syarifin dan Dedah Jubaedah, Ilmu Perundang-Undangan, Bandung: Pustaka Setia, 2012, h. 40.
} 
ijtihad atau inovasi dan invensi.Ada pula sarjana yang merumuskan sumber hukum Islam terdiri atas Al-Qur'an, Hadis, ijma', dan qiyas. Bahkan ada yang merumuskan sumber hukum Islam meliputi syari'at yang diwahyukan (wahyu), Sunnah sebagai teladan Rasul, dan akal dengan menggunakan metode berpikir tertentu. ${ }^{4}$

Menurut kajian ushul fikih, sering dibedakan antara pengertian sumber hukum (mashadir al ahkam) dengan dalil-dalil hukum (adillat al ahkam). Pengertian mashadir al ahkam secara teknis menunjuk kepada asal norma hukum, tempat ditemukannya kaidah hukum atau suatu yang menunjuk kepada adanya hukum, yaitu Al-Qur'an dan AsSunnah. Sedangkan adillat al ahkam merupakan sesuatu yang dijadikan landasan berpikir yang benar dalam memperoleh atau menemukan atau mendapatkan hukum.Hal yang dianggap sebagai adillat al ahkam ada empat, yakni Al Qur'an, As-Sunnah, ijma', dan qiyas. ${ }^{5}$

Pengertian sumber hukum demikian jelas berbeda dengan pengertian sumber hukum yang dipakai dalam ilmu hukum tata negara.Dalam hukum tata negara Indonesia, sumber hukum adalah Undang-Undang Dasar 1945 (selanjutnya disebut UUD 1945), Undang-Undang dan Perppu, Peraturan Pemerintah, Peraturan Presiden, dan Peraturan Daerah. Oleh sebab itu, pengertian sumber hukum dalam ilmu hukum tata negara jelas menunjuk pada pengertian sebagai peralatan dalam menilai suatu peristiwa hukum atau kaidah hukum yang bersifat konkret.

\section{Fatwa Sebagai Sumber Hukum Islam}

Istilah fatwa seringkali dihubungkan dengan hukum Islam, karena memang istilah ini berasal dari bahasa Arab, kaitannya dengan sumber hukum, fatwa bukanlah sumber hukum utama di dalam hukum Islam. Sumber hukum utama adalah Al-Qur'an dan AsSunnah. Fatwa sebagai hasil dari pemikiran manusia bukanlah sumber hukum utama, namun dapat dikategorikan ke dalam ijtihad, sebab proses penetapan fatwa dilakukan melalui metode-metode yang ditetapkan oleh ilmu ushul fikih. Pada praktik peradilan di Indonesia, fatwa dapat dimasukkan sebagai pendapat ahli hukum.Fatwa adalah legal

\footnotetext{
${ }^{4} I b i d .$, h. 41.

${ }^{5}$ Ibid., h. 42.
} 
opinion atau pendapat mengenai hukum Islam atas suatu persoalan yang dapat dijadikan sumber hukum sebagai pertimbangan hukum bagi hakim untuk memberikan putusan. ${ }^{6}$

Berdasarkan sumber hukum yang berlaku dalam sistem hukum nasional, yakni dalam sistem hukum nasional secara formal terdapat lima sumber hukum, adapun sumber hukum tersebut sebagai berikut: undang-undang, kebiasaan, putusan hakim (yurisprudensi), traktat, serta doktrin (pendapat pakar pakar/ahli hukum). Kemudian untuk dapat mengetahui tata urutan peraturan perundang-undangan yang berlaku di Indonesia, maka bisa dilihat dalam Undang-Undang No. 12 Tahun 2011 Tentang Pembentukan Peraturan Perundang-undangan, tepatnya dalam Pasal 7 yaitu hierarki perundang-undangan. Sumber hukum positif dalam sistem hukum nasional di atas dan dalam tata urutan peraturan perundang-undangan, sebagaimana telah disebutkan dalam Undang-Undang No. 12 Tahun 2011 Tentang Pembentukan Peraturan Perundangundangan, tidak menyebutkan fatwa sebagai bagian dari dasar hukum di negara ini, sehingga fatwa tidak dapat dijadikan sebagai landasan hukum.

Fatwa hanya sebagai suatu pendapat atau nasehat yang disampaikan oleh para ahli hukum Islam yang tergabung dalam suatu wadah organisasi, seperti Majelis Ulama Indonesia, Muhammadiyah, Nahdlatul Ulama, Persis, dan lembaga lainnya. Sehingga fatwa dapat dikorelasikan dengan sumber hukum formal dalam sistem hukum nasional, yakni kedudukan fatwa sama dengan doktrin yang merupakan pendapat pakar atau pendapat para ahli di bidang hukum positif. Dalam praktik, doktrin (pendapat ahli hukum) banyak mempengaruhi pelaksanaan administrasi Negara, demikian juga dalam proses pengadilan.

Seorang hakim diperkenankan menggunakan pendapat ahli untuk dijadikan sebagai pertimbangan hakim dalam memutus sebuah perkara, kemudian bagi seorang pengacara/pembela yang sedang melakukan pembelaannya pada suatu perkara perdata, seringkali mengutip pendapat-pendapat ahli sebagai penguat pembelaannya. Begitu pula dengan fatwa, dalam sejarah Peradilan Agama di Indonesia, Pengadilan Agama untuk dapat memeriksa, menangani, dan memutus perkara perdata (masalah kekeluargaan, kewarisan, perceraian, dan lain sebagainya), maka Pengadilan Agama memakai fatwa

\footnotetext{
${ }^{6}$ Yeni Salma Barlinti, Kedudukan Fatwa Dewan Syariah Nasional Dalam Sistem Hukum Nasional Di Indonesia, Jakarta: Badan Litbang dan Diklat Kementerian Agama Republik Indonesia, 2010, h. 98.
} 
sebagai landasan hukum, yakni fatwa disepakati oleh Mahkamah Agung bersama Pengadilan Agama. Kemudian sebagai contoh bahwa fatwa juga telah digunakan oleh hakim sebagai pertimbangan dalam memutus perkara perdata yakni pada Undang-Undang Nomor 3 Tahun 2006 tentang Pengadilan Agama disebutkan bahwa Pengadilan Agama berwenang untuk menyelesaikan sengketa ekonomi syari'ah, maka dari itu produk fatwa MUI dijadikan sebagai dasar untuk memutus sebelum ada undang-undang tentang ekonomi syari'ah, misalnya fatwa MUI No 21 tahun 2001 tentang pedoman umum asuransi syari'ah, fatwa MUI No 3 Tahun 2003 tentang Zakat Penghasilan, dan fatwafatwa lain tentang ekonomi yang berbasis syari'ah.

Fatwa sebagai pendapat ahli dalam hukum Islam dan doktrin sebagai pendapat ahli dalam hukum positif dapat dipakai sebagai pertimbangan hakim dalam memutus perkara perdata, namun tidak semua produk fatwa maupun doktrin dipakai oleh hakim, akan tetapi sebagian kecil saja dari fatwa ulama maupun doktrin (pendapat ahli hukum positif). Selain itu, fatwa juga mempunyai beberapa perbedaan mendasar dengan doktrin. perbedaan antara fatwa dan doktrin yakni pertama, dilihat dari objek yang menjadi fokus pembahasan, pada fatwa yang menjadi fokus pembahasan adalah berkenaan dengan persoalan agama, khususnya permasalahan hukum Islam. Sedangkan doktrin yang menjadi focus pembahasan adalah permasalahan dalam hukum positif. Kedua, dari segi waktunya fatwa berlaku saat ini juga, sejak fatwa tersebut dikeluarkan oleh lembaga yang bersangkutan, sedangkan doktrin berlaku kemudian setelah doktrin tersebut dikeluarkan oleh para pakar dan kadangkala juga harus diuji terlebih dahulu untuk dapat dipakai dan diberlakukan.Ketiga, fatwa dapat disampaikan secara individual dan secara kolektif, akan tetapi untuk saat ini seringkali disampaikan secara secara kolektif, sedangkan doktrin biasanya dikeluarkan oleh seorang ahli atau seorang pakar hukum.

Hanya saja apabila dilihat dari segi substansi sosiologis, fatwa tidak sama dengan doktrin. Fatwa sebagai sebuah penjabaran dari sumber hukum Islam, yakni Al Qur'an dan Hadis, memiliki otoritas hukum yang mutlak diikuti serta mengikat umat Islam. Hal ini diperkuat oleh teori penerimaan otoritas hukum Islam, dimana setiap orang yang telah mengucapkan dua kalimat syahadat, serta mengakui bahwa dirinya telah memeluk agama Islam, secara mutlak terikat pada ketentuan-ketentuan hukum Islam. Disinilah fungsi fatwa sebagai "penjelas" dan "jawaban pertanyaan hukum" yang merupakan jabaran 
teknis nash-nash yang sifatnya umum. Sehingga adanya kekuatan mengikat suatu fatwa bagi umat Islam yang berkewajiban tunduk kepada hukum Islam.

\section{Konstruksi Fatwa sebagai Sumber Hukum Islam}

Fatwa merupakan salah satu institusi dalam hukum Islam untuk memberikan jawaban dan solusi terhadap problem yang dihadapi umat. Bahkan umat Islam pada umumnya menjadikan fatwa sebagai rujukan di dalam bersikap dan bertingkah laku. Sebab posisi fatwa di kalangan masyarakat umum, laksana dalil di kalangan para, mujtahid (al-Fatwa fi Haqqil 'Ami kal Adillah fi Haqqil Mujtahid), artinya, kedudukan fatwa bagikebanyakan, seperti dalil bagi mujtahid. ${ }^{7}$

Fatwa merupakan sebuah upaya ulama untuk merespon masalah yang dihadapi masyarakat yang memerlukan keputusan hukum.Dasar hukum fatwa adalah al-Quran, Hadits dan Ijtihad.Kecenderungan penalaran yang dilakukan oleh para ulama dalam menjawab suatu permasalahan terkait erat dengan ijtihad atau pendapat hukum (legal opinion). Oleh karena itu ada 3 (tiga) hal yang penting terkait dengan fatwa, yaitu:

a. Pihak-pihak yang berkepentingan terhadap fatwa, seperti Pemerintah. Bank Indonesia, lembaga keuangan syariah (lembaga perbankan syariah) dan masyarakat sebagai pengguna jasa lembaga keuangan syariah;

b. Masalah atau persoalan yang diperlukan ketetapan hukumnya dikarenakan belum jelas hukumnya;

c. Para ulama yang mengerti hukum syariat, mempunyai otoritas mengeluarkan fatwa, dalam hal ini adalah Majelis Ulama Indonesia, yang pada praktiknya, dalam masalah ekonomi syariah, kewenangan ini didelegasikan kepada Dewan Syariah Nasional sebagai lembaga bentukan Majelis Ulama Indonesia dalam membuat fatwa yang terkait dengan masalah ekonomi syariah. ${ }^{8}$

Kedudukan Fatwa dalam hukum Islam dapat dikaji dari pengertian fatwa itu sendiri. Sehingga bila berbicara mengenai fatwa itu sendiri, maka tidak akan lepas dari aspek siapa atau organisasi apa yang membuat fatwa tersebut. Sehingga dapat disimpulkan bahwa berbicara tentang fatwa, maka tidak terlepas pembicaraan tersebut

\footnotetext{
${ }^{7}$ Zainuddin Ali, Hukum Ekonomi Syariah, Jakarta: Sinar Grafika, 2008, h. 127.

${ }^{8}$ Akhyar Ari Gayo, dkk, Kedudukan Fatwa MUI dalam Upaya Mendorong Pelaksanaan Ekonomi Syariah, Jakarta: Badan Pembinaan Hukum Nasional Kementerian Hukum dan HAM RI, 2013, h. 75-76.
} 
terhadap konsep ijtihad. Fatwa dikeluarkan oleh para ulama atau ahli fikih Islam yang mampu mengangkat permasalahan akibat kebutuhan siapa yang butuh dasar jawaban sebagai landasan hukum suatu perbuatan atau kegiatan yang sifatnya bisa keagamaan atau non-keagamaan.

Adanya korelasi yang erat antara fatwa dan ijtihad menunjukkan bahwa secara otomatis memperkokoh posisi ijtihad.Fatwa itu sendiri merupakan hasil ijtihad para ahli atau pakar yang mampu menggali syariat Islam, kemudian dari hasil ijtihad tersebut dituangkan dalam bentuk keagamaan, baik yang bersifat lisan ataupun tidak. Dengan adanya fatwa dan ijtihad maka secara konkret ajaran-ajaran Islamakan berkembang dengan pesat ke seluruh penjuru dunia, sekaligus Islam akan kokoh dan memasyarakat di alam ini. Oleh karena itu sangat tepat apabila dikatakan bahwa maju mundurnya masyarakat Islam, dalam menggali ajarannya tergantung dari fatwa dan ijtihad. Tanpa adanya fatwa dan ijtihad, ajaran-ajaran Islam kurang berkembarig bahkan nyaris statis, sebab kita mengetahui bahwa inspirasi yang murni dalam menggali ajaran-ajaran Islam itu idealnya melalui proses ijtihad yang kemudian dituangkan dalam bentuk fatwa keagamaan yang mantap dan dapat dipertanggungjawabkan.

Fatwa dan ijtihad terjadi hubungan saling interdepensi, sebab hasil ijtihad para ahli itu akan lahir dalam bentuk fatwa-fatwa yang berharga untuk kepentingan masyarakat Islam. Dapat dibuktikan bahwahasil fatwa atau ijtihad hukum Islam dapat hidup dan berkembang sesuai dengan ruang dan waktu dimana saja penganutnya hidup. Hakikatnya hukum-hukum yang dikembangkan itu selaras dengan masyarakat itu sendiri yang senantiasa disesuaikan dengan kondisi masyarakat. Dalam arti ijtihad dan fatwa akan selalu mengikuti perkembangan pemikiran masyarakat pada umumnya.

Menurut hukum Islam, dalam proses istinbath pengambilan hukum diatur dalam suatu kajian keilmuan tersendiri. Dalam ilmu hukum Islam disebut ilmu Ushul Fiqh. Secara umum pengertiannya adalah pengertian tentang kaidah-, kaidah yang dijadikan sarana (alat) untuk menggali hukum-hukum fiqh, atau dengan kata lain adalah kaidahkaidah yang menjelaskan tentang cara (metode) pengambilan (penggalian) hukum-hukum yang berkaitan dengan perbuatan manusia dari dalil-dalil syar'i. ${ }^{9}$

\footnotetext{
${ }^{9}$ Muhammad Abu Zahrah, Ushul Fiqh, Jakarta: Pustaka Firdaus, 1999, h. 3.
} 


\section{a. Aspek Filosofis Konstruksi Fatwa dalam Hukum Islam}

Fatwa sebagai suatu produk mufti atau pemberi fatwa, yang tidak sembarang orang atau institusi atau lembaga berwenang untuk mengeluarkan fatwa, ada syaratsyarat yang harus dipenuhi secara keilmuan dan keimanan. Banyak syarat-syarat yang harus dipenuhi oleh mufti atau pemberi fatwa, diantaranya sebagaimana disebutkan oleh Al-Nawawi, yaitu Mukallaf; Muslim; Berkepribadian kuat; Dapat Dipercaya; Suci dari sifat-sifat tercela; Berjiwa kuat; Berotak cemerlang; Berpikiran tajam; Bisa melakukan istinbath hukum; Sehat jasmani dan rohani, maupun syarat-syarat lain. Mufti atau pemberi fatwa ini sendiri dalam memberikan fatwa dapat dilakukan sendiri (ijtihad fadiy) atau secara kelompok (ijtihad jama'i).

Terkait dengan Dewan Syariah Nasional- Majelis Ulama Indonesia (DSNMUI) sebagai pihak pemberi fatwa, apabila dilihat dari sifat organisasi, MUI sebagai sebuah lembaga yang mewadahi ulama zu'ama dan cendekiawan Islam di Indonesia, dan beranggotakan para ulama dari berbagai kalangan, baik kalangan tradisionalis maupun modernis yang mempunyai tugas untuk memberikan bimbingan dan tuntunan kepada umat Islam dalam kehidupan beragama dan bermasyarakat yang diridhoi Allah SWT; memberikan nasehat dan fatwa mengenai masalah keagamaan dan kemasyarakatan kepada Pemerintah dan masyarakat. Maka apabila melihat komposisi personalia dan tugas MUI tersebut, MUI adalah sebagai lembaga yang mempunyai kewenangan untuk mengeluarkan fatwa, hal ini terlihat dari fakta, bahwa sejak pendiriannya hingga sekarang, MUI telah mengeluarkan banyak fatwa, baik berkaitan dengan masalah ritual keagamaan, pernikahan, kebudayaan, politik, ilmu pengetahuan, maupun transaksi ekonomi. Dalam perkembangan selanjutnya, MUI menganggap perlu mendirikan Dewan Syariah Nasional (DSN), sebagai lembaga otoritas pemberi fatwa tentang ekonomi syariah di Indonesia, yang kedudukan organisasinya berada di bawah Majelis Ulama Indonesia. Komposisi anggota plenonya terdiri dari para ahli syariah dan ahli ekonomi/keuangan yang mempunyai wawasan syariah.Dalam membahas masalah-masalah yang hendak dikeluarkan fatwanya, Dewan Syariah Nasional (DSN) melibatkan pula lembaga mitra seperti Ikatan Akuntan Indonesia dan Bank Indonesia. 
Fatwa secara filosofis merupakan jawaban permasalahan hukum yang menjelaskan intisari nash-nash dalam menghadapi kebuntuan umat Islam menghadapi permasalahan-permasalahan hukum Islam kontemporer.Sebab, menurut Ibnu Taimiyyah, hukum Islam dapat diklasifikasikan menjadi dua bentuk dasar, yakni syari'ah munazzalah (ketentuan yang diturunkan) dan syari'ah muawwalah (ketentuan yang ditafsirkan).Syari'at yang diturunkan ialah Al Qur'an dan Hadis, sedangkan syari'at yang ditafsirkan, salah satunya, adalah melalui fatwa ulama.Oleh sebab itu, fatwa sebagai alternatif menghadapi kebuntuan jawaban permasalahan hukum Islam, bersifat dinamis sebagaimana dinamisnya problematika hukum Islam. Hal ini dibahas oleh Ibnu Qayyim di dalam kitab I'lamul Muwaqi' in (Panduan Hukum Islam), dengan membuatkan bab khusus yang diberi judul, "Taghayyur al-Fatwa wa Ikhtilafuha bi Hasab Taghayyur al-Azminah wa al-Amkinah wa al-Ahwal wa al-Niyyat wa al-Awaid" (Perubahan fatwa dan perbedaannya berdasarkan perubahan zaman, tempat, kondisi social, motivasi dan adat-istiadat). ${ }^{10}$

\section{b. Aspek Yuridis Konstruksi Fatwa dalam Hukum Islam}

Fatwa sebagai suatu dalil atau pendapat hukum yang berfungsi menjelaskan suatu hukum/peraturan, maka apakah sifat dari fatwa tersebut mempunyai kekuatan mengikat bagi pihak peminta fatwa, pemberi fatwa maupun masyarakat luas. Secara teori, fatwa dalam definisi klasik bersifat opsional "ikhtiyariah" (pilihan yang tidak mengikat secara legal, meskipun mengikat secara moral bagi mustafti, sedangkan bagi selain mustafti bersifat informatif yang lebih dari sekedar wacana. Namun apabiia melihat praktik kegiatan perbankan syariah di Indonesia, maka teori fatwa hanya mengikat mustafti tidak relevan untuk fatwa DSN-MUI. Fatwa ekonomi syariah DSNMUI saat ini tidak hanya mengikat bagi praktisi lembaga ekonomi syariah, tetapi juga bagi masyarakat Islam Indonesia.Sifat mengikat dari fatwa DSN-MUI itu sendiri tidak serta merta mengikatsecara langsung para stakeholders, namun mengikat apabiia rumusan-rumusan pendapat hukum dalam Fatwa DSN-MUI tersebut dituangkan dalam Peraturan Bank Indonesia (PBI).

\footnotetext{
${ }^{10}$ Ibnu Qayyim Al Jauziyah, I'lamul Muwaqi'in (Panduan Hukum Islam), terjemah oleh Asep Saefullah dkk, Jakarta: Pustaka Azzam, 2000, h. 459.
} 
Fatwa DSN-MUI memiliki fungsi menjelaskan hukum yang merupakan regulasi praktis bagi lembaga keuangan, khususnya yang diminta praktisi ekonomi syariah ke DSN-MUI dan Taujih. yakni memberikan guidance (petunjuk) serta pencerahan kepada masyarakat luas tentang norma ekonomi syariah. Kehadiran fatwafatwa ini menjadi aspek organik dari bangunan ekonomi Islami yang tengah ditata/dikembangkan. sekaligus merupakan alat ukur bagi kemajuan ekonomi syariah di Indonesia. Fatwa ekonomi syariah yang telah hadir itu secara teknis menyuguhkan model pengembangan bahkan pembaharuan fiqh muamalah maliyah (fiqh ekonomi). ${ }^{11}$

Ada hal menarik ketika mengkaji fatwa ditinjau dari aspek yuridis, dimana terjadi transformasi fatwa dari yang sifatnya tradisional ${ }^{12}$ menjadi fatwa yang sama sekali baru.Fatwa DSN-MUI secara formal bersifat mengikat dan wajib diikuti oleh Lembaga Keuangan Syariah, khususnya Perbankan Syariah. Hal ini dikuatkan dengan adanyaUndang-Undang Nomor 21 Tahun 2008 tentang Perbankan Syariahyang mengharuskan Perbankan Syariah meminta legitimasi dari fatwa DSN-MUI setiap kali ingin meluncurkan produk terbaru. ${ }^{13}$ Oleh sebab itu, fatwa DSN-MUI memiliki kedudukan yang kuat secara yuridis terhadap aktifitas Perbankan Syariah.

\section{c. Aspek Sosiologis Konstruksi Fatwa dalam Hukum Islam}

Momentum berdirinya MUI bertepatan ketika bangsa Indonesia tengah berada pada fase kebangkitan kembali, dimana energi bangsa telah banyak terserap dalam perjuangan politik kelompok dan kurang peduli terhadap masalah kesejahteraan rohani umat.Ulama Indonesia menyadari sepenuhnya bahwa mereka adalah pewaris tugastugas para Nabi (Warotsatul Anbiya).Maka mereka terpanggil untuk berperan aktif dalam membangun masyarakat melalui wadah MUI, seperti yang pernah dilakukan oleh para ulama pada zaman penajajahan dan perjuangan kemerdekaan. Di sisi lain umat Islam Indonesia menghadapi tantangan global yang sangat berat. Kemajuan sains dan teknologi yang dapat menggoyahkan batas etika dan moral, serta budaya global yang didominasi Barat, serta pendewaan kebendaan dan pendewaan hawa nafsu yang

\footnotetext{
${ }^{11}$ Antonio Sjafi'i, Bank Syariah dari Teori Ke Praktek, Jakarta: Gema Insani Pers, 2001, h. 147-148.

${ }^{12}$ Fatwa klasik yang secara formal tidak mengikat mustafti.

${ }^{13}$ Pasal 26 Undang-Undang Nomor 21 Tahun 2008 tentang Perbankan Syariah.
} 
dapat melunturkan aspek religiusitas masyarakat serta meremehkan peran agama dalam kehidupan umat manusia. ${ }^{14}$

Selain itu kemajuan dan keragaman umat Islam Indonesia dalam alam pikiran keagamaan, organisasi sosial dan kecenderungan aliran dan aspirasi politik, sering mendatangkan kelemahan dan bahkan dapat menjadi sumber pertentangan di kalangan umat Islam sendiri. Akibatnya umat Islam dapat terjebak dalam egoisme kelompok (ananiyah hizbiyah) yang berlebihan.Oleh karena itu kehadiran MUI, makin dirasakan kebutuhannya sebagai sebuah organisasi kepemimpinan umat Islam yang bersifat kolektif dalam rangka mewujudkan silaturrahmi, demi terciptanya persatuan dan kesatuan serta kebersamaan umat Islam. ${ }^{15}$

Berdasarkan pendekatan historis (historical approach) dalam perjalanannya, selama dua puluh lima tahun Majelis Ulama Indonesia sebagai wadah musyawarah para ulama, zu'ama dan cendekiawan muslim berusaha untuk memberikan bimbingan dan tuntunan kepada umat Islam dalam mewujudkan kehidupan beragama dan bermasyarakat yang diridhoi Allah SAW; memberikan nasihat dan fatwa mengenai masalah keagamaan dan kemasyarakatan kepada Pemerintah dan masyarakat, meningkatkan kegiatan bagi terwujudnya ukhwah Islamiyah dan kerukunan antar-umat beragama dalam memantapkan persatuan dan kesatuan bangsa serta; menjadi penghubung antara ulama dan umaro (pemerintah) dan penterjemah timbal balik antara umat dan pemerintah guna mensukseskan pembangunan nasional; meningkatkan hubungan serta kerjasama antar organisasi, lembaga Islam dan cendekiawan muslimin dalam memberikan bimbingan dan tuntunan kepada masyarakat khususnya umat Islam dengan mengadakan konsultasi dan informasi secara timbal balik. ${ }^{16}$

Di dalam Pasal 3 Pedoman Dasar MUI yang disahkan Musyarawarah Nasional (Munas) I pada 26 Juli 1975, disebutkan bahwa MUI bertujuan untuk turut serta mewujudkan masyarakat yang aman sesuai dengan Pancasila, UUD Negara Republik Indonesia Tahun 1945 dan Garis-Garis Besar Haluan Negara. Pada Munas II, Pasal 3 Pedoman Dasar MUI tersebut telah disempurnakan menjadi:

\footnotetext{
${ }^{14}$ Akhyar Ari Gayo, dkk, Kedudukan Fatwa MUI dalam Upaya Mendorong Pelaksanaan Ekonomi Syariah, Jakarta: Badan Pembinaan Hukum Nasional Kementerian Hukum dan HAM RI, 2013, h. 44.

${ }^{15} \mathrm{Ibid}$.

${ }^{16}$ Ibid., h. 44-45.
} 
"MUI bertujuan ikut serta mewujudkan masyarakat yang aman, damai, adil dan makmur rohaniah dan jasmaniah sesuai dengan Pancasila, UUD Negara Republik Indonesia Tahun 1945 dan Garis-Garis Besar Haluan Negara yang diridhoi oleh Allah, SWT. Sedangkan pada Munas III yang berlangsung pada 23 Juli 1985, Pasal 3 Pedoman Dasar MUI disempurnakan menjadi: "MUI bertujuan mengamalkan ajaran Islam untuk ikut serta mewujudkan masyarakat yang aman, damai, adil dan makmur rohaniah dan jasmaniah yang diridhoi oleh AllahSWT dalam negara Republik Indonesia yang berdasarkan Pancasila. ${ }^{17}$

Secara sosiologis tugas utama MUI adalah membina dan membimbing umat untuk meningkatkan keimanan dan mengamalkan ajaran-ajaran agama Islam, dalam usaha untuk mewujudkan masyarakat yang aman, adil dan makmur rohaniah dan jasmaniah sesuai dengan Pancasila, UUD 1945 dan Garis-Garis Besar Haluan Negara, sedangkan peran MUI sebagaimana dirumuskan oleh Munas I dalam Pedoman Dasar Pasal 4, yaitu berperan untuk mengeluarkan fatwa dan nasihat kepada pemerintah dan umat Islam dalam masalah yang berhubungan dengan masalah keagamaan dan kemaslahatan bangsa, menjaga kesatuan umat, institusi representasi umat Islam dan sebagai perantara yang mengharmonisasikan hubungan antara umat beragama. ${ }^{18}$ Secara umum pendapat fatwa selalu memperhatikan kemaslahatan umum (maslahah 'ammah)dan tujuan hukum Islam (maqashid syariah),sehingga fatwa benar-benar menjawab permasalahan yang dihadapi umat dan benar-benar menjadi alternatif untuk dijadikan pedoman. ${ }^{19}$

\section{Kesimpulan}

Fatwa menjadi salah satu institusi dalam hukum Islam untuk memberikan jawaban dan solusi terhadap problem yang dihadapi umat. Bahkan umat Islam pada umumnya menjadikan fatwa sebagai rujukan di dalam bersikapdan bertingkah laku.Sebab posisi fatwa di kalangan masyarakat umum, laksana dalil di kalangan para mujtahid (alFatwa fi Haqqil 'Ami kal Adillah fi Haqqil Mujtahid), artinya, kedudukan fatwa dalam konstruksi hukum Islam sebagaimana dalil bagi mujtahid. Kedudukan fatwa dalam

\footnotetext{
${ }^{17}$ M. Cholil Nafis, Teori Hukum Ekonomi Syariah, Jakarta: UI Press, 2011, h. 77.

${ }^{18}$ Ibid.

${ }^{19}$ Mardani, Ushul Fiqih, Jakarta: Rajawali Pers, 2013, h. 385.
} 
konstruksi hukum Islam yaitu menjadi landasan hukum terhadap suatu perbuatan atau kegiatan yang sifatnya ibadah maupun muamalah. Fatwa klasik bersifat opsional (ikhtiyariah) atau pilihan yang tidak mengikat secara legal. Namun, mengikat secara moral bagi mustafti atau seseorang yang meminta fatwa. Hal ini dikuatkan melalui teori penerimaan otoritas hukum Islam, yang menjadi dasar kewajiban setiap umat Islam untuk tunduk dan patuh terhadap hukum Islam, yang sumbernya salah satunya adalah fatwa, baik dari aspek filosofis, yuridis, dan sosiologis.

\section{DAFTAR PUSTAKA}

Abdul Azis Dahlan (ed.), Ensiklopedi Hukum Islam, jilid 1, Jakarta: Ichtiar Baru Van Hoeve, 2000.

Abu Malik Kamal, Pengantar Ilmu Fikih, terjemah oleh Muhammad Ashim, Jakarta: Darus Sunnah Press, 2009.

Ahmad Sukardja dan Mujar Ibnu Syarif, Tiga Kategori Hukum: Syari'at, Fikih, dan Kanun, Jakarta: Sinar Grafika, 2012.

Akhyar Ari Gayo, dkk, Kedudukan Fatwa MUI dalam Upaya Mendorong Pelaksanaan Ekonomi Syariah, Jakarta: Badan Pembinaan Hukum Nasional Kementerian Hukum dan HAM RI, 2013.

Amir Syarifuddin, Ushul Fiqh, jilid 2, Jakarta: Kencana Prenada Media Group, Cet. ke-V, 2009.

Antonio Sjafi'i, Bank Syariah dari Teori Ke Praktek, Jakarta: Gema Insani Pers, 2001.

Dewan Redaksi Ensiklopedi Islam (ed.), Ensiklopedi Islam, jilid 2, Jakarta: Ichtiar Baru Van Hoeve, 1993.

Eddi Rudiana Arief, dkk, Hukum Islam di Indonesia, Remadja Rosdakarya, 1994.

Ellydar Chaidir dan Sudi Fahmi, Hukum Perbandingan Konstitusi, Yogyakarta: Total Media, 2010.

Gayo, Akhyar Ari, dkk, Kedudukan Fatwa MUI dalam Upaya Mendorong Pelaksanaan Ekonomi Syariah, Jakarta: Badan Pembinaan Hukum Nasional Kementerian Hukum dan HAM RI, 2013.

Ibnu Qayyim Al Jauziyah, I'lamul Muwaqi'in (Panduan Hukum Islam), terjemah oleh Asep Saefullah dkk, Jakarta: Pustaka Azzam, 2000.

Jefry Tarantang, Teori dan Aplikasi Pemikiran Kontemporer dalam Pembaharuan Hukum Keluarga Islam, Jurnal Transformatif Vol. 2, No. 1, April 2018.

Khairul Uman, Ushul Fiqh II, cet. II, Bandung: Pustaka Setia, 2001.

M. Cholil Nafis, Teori Hukum Ekonomi Syariah, Jakarta: UI Press, 2011.

Ma'ruf Amin, Fatwa Dalam Sistem Hukum Islam, Jakarta: eLSAS, 2008.

Mardani, Ushul Fiqih, Jakarta: Rajawali Pers, 2013.

Muhammad Abu Zahrah, Ushul Fiqh, Jakarta: Pustaka Firdaus, 1999.

Muhammad bin Shalil Al-Utsaimin, Ushul Fiqih, terjemah oleh Ahmad S Marzuqi, Yogyakarta: Media Hidayah, 2008.

Pipin Syarifin dan Dedah Jubaedah, Ilmu Perundang-Undangan, Bandung: Pustaka Setia, 2012. 
El-Mashlahah, Vol. 9, No. 2, 2019

Yeni Salma Barlinti, Kedudukan Fatwa Dewan Syariah Nasional Dalam Sistem Hukum Nasional Di Indonesia, Jakarta: Badan Litbang dan Diklat Kementerian Agama Republik Indonesia, 2010.

Yusuf Qardhawi, Fatwa Antara Ketelitian dan Kecerobohan, Diterjemahkan oleh As'ad Yasin dari buku asli yang berjudul "Al-Fatwa Bainal Indhibat wat-Tasayyub", Jakarta: Gema Insani Press, 1997.

Zainuddin Ali, Hukum Ekonomi Syariah, Jakarta: Sinar Grafika, 2008. 